\title{
Identity practice: A study of Bangladeshi Immigrants Leisure Subculture and Identity Practices in Tallinn, Estonia
}

\author{
Aminul Islam \\ Institute of International and Social Studies, Tallin University, Estonia
}

\section{Introduction}

Bangladeshi immigrant social gatherings for the game of cricket have been around in Tallinn for more than five years. In 2011, some four or five people started playing Cricket in their neighborhood during the spring and summer time on Friday, Saturday or weekend basis and on any Estonian or even Bangladeshi national holidays or festival events. They continued this event and later on a number of Bangladeshi immigrants in and around Tallinn started attending this event. There was very little number of Bangladeshi immigrants living in Tallinn when they started, according to the respondents, it was around 20 to 25 Bangladeshi immigrants all together. There is no particular statistics about how many Bangladeshi immigrants were living in Tallinn in the year 2017. According to the respondents it is around 200. On a Sunday afternoon in April 2017, I, a Bangladeshi man, a doctoral student at Tallinn University followed a friend into the immigrant social gathering for cricket game; expectation was to get some people to interview for my project on Bangladeshi immigrants in Estonia. It was fascinating to get involved with immigrant's leisure subculture and work for more than two months on it. I figured that the game of cricket in a very exclusive way exposed the emotional, cultural and social repercussion of migration for those who are new in Estonia.

\section{Ethnicity and Leisure time}

The number of "Other Background" immigrants in Estonia consists of 0.8 percent of entire population, which in number is 10,912, that includes Oceania/South Asian/South American and Middle Eastern Immigrants (Statistics Estonia, 2017). This ethnography in my opinion would be the first study and sociological investigation among the group of immigrants, who are from Bangladesh. This paper aims to investigate two questions: In a leisure subculture, what do Bangladeshi immigrants do and our understanding about different immigrant leisure subculture. 
This investigation specifically would try to investigate our understanding of status practices and identity issues in the immigrant cricket game ground.

Studies that focused on immigrant leisure time, many of them take their departure point by emphasizing on the separation of immigrant leisure space from the mass population or host countries population as a reaction to constraints that includes cultural and social differences and isolation, less knowledge about host society and their language skills (Stoldolska, 1998; Rublee \& Shaw, 1991). The constraints that have been focused in earlier studies some of them are caused by perceived discrimination. It is evident by many studies that people with different ethnic background with different phenotypes, faced discriminatory attitude in their leisure venue that are public in places, and ethnic minorities retreat those leisure exercise to avert discrimination (Chavez 1991, 1993 cited in Stoldolska \& Jackson, 1998). Different studies figured that interacting or socializing with other ethnics comes in to the form of reaction to discrimination, in other cultural and social platforms, work place for instance (Pankiw \& Bienvenue, 1990; Li, 1987; Feagin, 1991). A study on Polish immigrants in Alberta, Canada, Stoldoska and Jackson (1998) found out that because of many immigrants faced perceived discrimination in their daily life, they come up with their leisure decisions which offered options for recuperation from discrimination at school or work place.

Formation of ethnic identity and solidarity has been emphasized as immigrant leisure culture in traditional immigrant community studies. In an investigation on Italian immigrants in Chicago, America, Poe (2001) stated that food making was a point that turned Italian immigrants to consolidate their different regional identities in unique Italian American identity in the late nineteenth and early twentieth century. They came from different regions of Italy, had different customs or rituals but their eating turned a focus for mutual memory and that leads ethnic identity construction. In the twentieth century, Immigrant saloon for instance created single ethnic group (Noel, 1977; Kingsdale, 1973). Saloon at times was used to conserve ethnic customs. This place was used as a place for meetings and also to celebrate festivals related to origin country. In an investigation on Mexican immigrants in America Alarcon, Durand and Gonzalez (1987) pointed out that frequent contact can be prompted by variety of Institutional mechanism that reinforces their ethnic networks. In this research they figured how a soccer clubs bring immigrants together that too, on a regular basis that bring information and exchange among them.

Research on immigrants in Estonia mostly focused on Russian speaking first or second generation immigrants putting the emphasize on educational level of immigrant's population, position of native and immigrant's population in the labor market, working life of native and immigrant population, ethnic minority and 
majority unions, political and civic participation of immigrants etc. To examine the relationship between structural, cultural, social and identificational integration dimensions among second generation Russians in Estonia, Nimmerfeldt (2011) and his colleagues identified that in Estonia, relationship between structural and cultural integration is positive and according to this study higher level of social and identificational integration is not related to higher level of structural integration. Second generation Russian retains a strong ethnic identity and socializes primarily with other Russians. Ham and Tammaru (2003) in their research on ethnic minority and majority unions in Estonia came out with a finding that Russian speaking immigrant women are less likely to make a union which according to them is ultimate evidence of the integration of ethnic minorities into the host societies. In a study of political and civic participation of second generation Russian and Estonian Youth, Schulze (2014) pointed out that 'Ethnicity remains a significant predictor of political and civic participation. Estonians are more likely to vote in municipal elections and to participate in a voluntary association than Russian' (p.19). However, the percentage of individuals with low level of education is lower among immigrants than among native population (Saar, 2009). Migration research in Estonian society has been mostly built on Russian speaking immigrant and immigrants on the whole. None of them particularly focused on refugees or immigrants having the ethnic background outside of Europe.

This paper, by investigating Bangladeshi Immigrants Cricket game practices, argues that Leisure subculture for the immigrants is in the first place a combine or collective counter to problems incurred in migration process. In case of Bangladeshi immigrants playing cricket game subculture, the cricket ground was place where immigrants not only retrieve or develop their ethnic identity or networks, but they also achieve their personal or individual identity and recover their status damaged in the process of migration.

\section{Data and Method}

Two months' participant observation was carried out for this ethnography and indepth interviews with multiple participants in the Bangladeshi immigrant's social gathering for cricket sport. From April to May 2017, I tried to attend on a regular basis in any kind of parties before and after the gathering for the cricket game. I tried to establish friendly and personal relationship with organizers who organized this event and also other participants who took part the game. Those who attended the event quite often knew I was doing a research in the field. They were rather willing to provide insightful information and this way they turned a very relied sources of 
gossip and information. In May, I myself started attending the game, which helped me to become more associated with the participants.

Through this approach I was able to carry out open, semiformal and formal interviews with nineteen participants who I met through the field. Out of these interviewees thirteen were men and five were women, these women, however, never took part of the game but were accompanying their partner or relatives. I tried to approach in a way, while myself playing, in my team members I tried to introduce my research and to see if anyone showed any interest and was talking about these issues during the play and afterwards. This way I asked their phone number and tried to see if I could conduct interview later. Another approach was lunch gathering. Usually after the game is finished, they would be divided into several groups and would go for lunch. In the lunch table names and phone numbers have been exchanged between and among the members. In this process I tried and figured some new members to invite for a talk. Another way to approach was just to turn to the members who were playing in the field and directly inform them what I have been doing in my research and ask them if they would be interested to go for an interview. Organizers of the game were one of the very few cases I approached in this way.

Interviews have been conducted at a Pizza shop or a restaurant on a lunch table, lasted for about half or an hour. Open interviews could go even longer and at times participants invited me to go to their place and to have conversation or friendly discussion after the interview. Most of the information has been picked in this way.

Interviewees usually talked about their experiences in Estonian, their life story, expectations and the reason for participating the game of cricket. Other than interviews, I took field notes of each game gathering. I tried to take notes of what they did, what did they say and if there is anything special or unusual. I wrote the field notes during the night after the interviews based on my memory, and also some voice recording and notes that I took whenever I could during the course of interview or observation. Through grounded theory approach the data were processed (Strauss $\&$ Corbin, 1990). Themes were derived from open coding.

\section{Bangladeshi Immigrants Game of Cricket gathering in Tallinn}

Bangladeshi Immigrants Cricket game gathering started almost five years back as a social gathering among Bangladeshi students mostly and also some professionals and businessman. The gathering that I focused was based on a field called "Hipodrom", this is a regular gathering place, normally during the weekends and any other Bangladeshi festival days or Estonian national holidays. There is no formal 
advertising for this event. Through social media they get to know about it, there is a Facebook group called "Bangladeshis living in Estonia", through this platform this event was created.

Normally the game goes for around three to four hours, starting from early in the morning 9 a.m. to 12 noon or 13 p.m. This is a free event; members who regularly play cricket pay for the cricket bat and ball, which doesn't cost that much. Five euros a month is enough for that.

Outside the game field women and other men who do not play, would sit or stand together, would gossip in their own language. Some brings Bangladeshi traditional food to have them together with other community members, some do play Bangladeshi songs in their mobile while the rest would play and make fun. I noticed that even though the whole gathering was for play, but the playing part is essentially a basis through that people meet and talk and discuss about their life, expectation and what is going on around.

When the game is over, some would go directly to their home, some of them would still hang around, would go for lunch together, more often they go to Indian restaurant nearby where some of them do work as a part timer or full timer. They get special discount from the restaurant. Some of them would even go from lunch table to their home for the dinner and to make a Bangla party, where they will play Bangla music and have some fun by talking and making laugh on each other.

Some existing literature figured that social gathering can be described as segregated by class (Roy, 1997; Peiss, 1986). Bangladeshi immigrants' game gathering was mostly organized by the students but also attracted other professionals, businessman and other socioeconomic background's people and also some of them came from the southern city of Tartu. Among the participants I got university teacher, $\mathrm{PhD}$ students, masters and bachelor level students, IT expert, restaurant owners, house wives and some worker in different sectors. Bangladesh is large country, what I identified is that most of the immigrants of this gathering from Sylhet, Chittagong and Dhaka region.

Age wise most participants were between their early twenties and early thirties. This was partly because most of them were either students or young professionals and also the fact the cricket became popular in the 90s in Bangladesh. Therefore, younger generations grew up with cricket as their recreational opportunities, whereas earlier generation might find football or any other activities as their recreational activities. 
This game of cricket also attracted for mostly the single men, even though some of their wives were present, despite the fact that they were not playing, as cricket is widely viewed as men's game in Bangladesh.

\section{Practice of status and identification through Game gathering}

This cricket game gathering was a cheap recreational activity for Bangladeshi immigrants. They attended this gathering to have some physical exercise, to have some relaxed time, to meet new people in the community and to make friendship.

\section{Acting Bangladeshi}

Most of the Bangladeshi immigrants attended the game gathering to find company from other country mate, talk in Bangla language. Game organizers made sure that the environment is rather friendly and Bangla music during the event plays its part. Being conscious as Bangladeshi played a role during the gathering. Yakub, a 25year-old student says "cricket is a part of younger generation Bangladeshi and I come here to feel a little bit of Bangladeshiness"

\section{Performing Bangladeshi Identity through celebration}

On the $14^{\text {th }}$ April, I saw there were different Bangladeshi foods being brought out by every members of the game gathering. The turnout was quite high. It was the Bangla New Year day. They started the gathering by singing a song "Esho he Boisakh, esho he esho", it's a song that welcomes the Bangla New Year. There was Bangla book offered by the organizers.

I recognized that I got into a very rare nationalistic emotional event on that day. They ended up game event by holding each other's hand and singing another Bangla song "amra korbo joy", we shall overcome.

In this very day, some local Estonian and other international students from different countries were invited to join with the Bangladeshi gathering. However, occasionally I could feel the antagonism towards other nationality as one member stated

"Foreigners almost ruined our event! We always had to show them how we did things in Bangladesh, in this process we could not act properly the way we normally celebrate our Bangla new year. We shouldn't have invited them in this day. They 
could come to any other weekend, if they wanted so. Organizers should think about $i t^{\prime \prime}$

\section{Sense of togetherness}

A very typical statement that came out from the participants is that "Bangladeshi people feel and act naturally when they are with other Bangladeshis." During the game event they chant, sought each other both in and out of the field shows empathy and understanding among them. A sense of togetherness was there. Rokon, a 33-year university teacher, explained the sense of collectivity 'In the game gathering you could talk with other people. I have the feeling that I belong to this group. Whenever I get into this gathering and someone greets me with the Bangla greeting, I feel like here I am with my group"

One participant whose wife was Estonian and most of her friends are from Estonia, when he speaks very little Estonian, he stated - "I feel kind of fellowship here in this gathering. You would find some friend to talk and go eating and drinking together." Some others who were married to local Estonian said that they found this gathering most social event for them and that they had some social freedom in this gathering. This was a gathering that goes beyond the game for them.

\section{Status practices through grouping at the social game gathering}

For many participants this game gathering was where their socializing started. After the game, they would divide into groups for different find of activities. More often they would go to lunch. Some would gather on a Saturday evening at their home. Some would go for some cultural activities. These groups had their selfconsciousness among them, and each group might have some core member followed by some peripheral members. The bases of the groups were built by their socioeconomic status, educational background, region and any particular interests. Self-identification has been reflected through this grouping. However, this grouping was rather fluid in boundary and that moving in and out was a constant matter.

\section{Region wise Grouping}

Bangladesh has different regional division and each division has its own dialect and culture. Usually whenever they meet with a new person in a social gathering the 
immediate question would be "which part of Bangladesh you come from?" The feasible groups that were identified was "Sylheti" and "Chittagong". One is Southeastern part of Bangladesh and the other is Southern part. As Sylheti people do have the tendency to go abroad, so they formed the highest in number even in Estonia as well, followed by Chittagong.

People from Sylhet do believe that they have specific life style and they might pose different personality than other parts of Bangladesh. This way of thinking was evident among the participants and also this feeling made them into a bonding. I was invited to a Sylheti gathering where more than fifteen people were present. As soon as I got into that gathering, I was asked "Which part of Sylhet I was from"? During this gathering, people were talking about their home town. Some also found that they had some mutual relatives or friends back in Bangladesh. I saw a food that was served with 'Satkora' this is kind of a special spice can be found that in that particular region in Bangladeshi and it holds very significant as their regional identity. Everybody was delighted in that lunch table finding 'Satkora' in their menu.

Interestingly, where Southeast part harmony was feeling in same qualities, Southern parts were more of not being able to get the same privilege by other group or being discriminated or feeling of less in number. As one guy from Southern part stated that

"I tried to hang around the Southeastern people initially, but none was good enough to hang. Now I only hang with people from Southern part. When you are with your hometown people, you can share everything they don't laugh on it, they try to understand and help you to solve the problem"

Those who had no education or less educated had strong regional bonding than those who were educated. It means those could not find any other stigma found it easier to form a group this way.

\section{Role of Education or Occupation to form group}

While I asked One Sylheti, who has been doing $\mathrm{PhD}$, "why did not you socialize yourself with other Sylheti? Said, 'Level is different". "Level" is the word, which I heard constantly from Bangladeshi immigrants. Educated people with better socioeconomic positions found themselves in a different group. A group that I participated was consisted by $\mathrm{PhD}$ and Masters Students. One 27-year-old lady, who was doing her $\mathrm{PhD}$, stated that 'I found other groups not suitable for me and too crowdie" 
It was the same for people who had low socioeconomic and educationally back groups. That PhD student informed,

'I invited one girl who I met at the game gathering to one of our lunch gatherings, I found she was embarrassed and other group members kept on asking where she went to school and was graduated, she was never graduated, so she found it embarrassing. People were anyway polite while asking though but yet she did not find it good".

\section{Grouping by activities and Interests}

Some participants who met each other during game gathering formed smaller groups. I found one group who like cooking formed a smaller group of three or four men and women. I found another who formed group who had partners from local society or from other country than Bangladesh. I was invited to a gathering as such, one 40year-old guy said "we are fixed circle because we are married and also, we had partners from different societies than Bangladesh. We can share and count us activates and feel good at it".

\section{Performing personal or individual status in the social gathering}

In a predominantly Estonian society; Bangladeshi immigrants are first seen as Bangladeshi or as immigrants. In this social gathering, in contrast, people were able to show their different statuses and to distinguish themselves among their community. This status could be achieved through their residential status, education, occupation, marital situation, even skills in play in the field. Status display and resources display was quite evident in this kind of social gathering.

Displays of socioeconomic status were also very much evident in this particular gathering. While owning a car would be nothing in Estonian culture, it becomes quite a status symbol for this kind of Bangladeshi gathering. Especially after the gathering, when people seek a lift to go home, the car owner becomes quite important, and also it shows the fact that he is quite settled within this host society. Women who were not playing, but were accompanying male partners, were also displaying status by talking about the costs of their ornaments or brand-name clothes.

\section{Figuring identity and status practices through leisure subculture}


Question can be asked which way we can understand immigrant leisure subculture through this identity and status practices? In my opinion this kind of Bangladeshi immigrant subculture is indeed a retreat for them as immigrants do have barriers and that perceived discrimination is quite often a case as well. It was evident through this social gathering that they practice a collective identity but at the same time I would argue that a person could even recover individual identities and status through kind of leisure social gathering.

It is quite evident from the narratives and practices by the Bangladeshi immigrants that this kind of social leisure gathering helped them escaping from social isolation and the stressful life that they lead. This is where they could talk in their own language, find each other company, and could perform different identity and social status from within the community.

\section{Sense of Collective (identity) and Individual (status)}

While Bangladeshi immigrants gathered in a field for cricket game, it gave them a collective identity and also it leads another question whether they were only constructing collective identity, or they were constructing their individual status and identity? In the Bangladeshi immigrant's subculture setting I would argue that yes it was in the first place for collective identity, but it also in a contrast view formed individual identity in many ways. Number of Bangladeshi respondents came to join this kind of gathering to enjoy the recognition their individual status they would not find out side of this community.

For example, Hamid, a 30-year-old refugee, who is well educated and has a $\mathrm{PhD}$ in Mathematics found a new status through PhD students gathering, what he came to know from the game gathering. He stated that,

"I was just a refugee for others, before I found this group or small community. When I got to know this kind of PhD students gathering and their discussion topics, I got along nicely with them; and this way retrieve my own status and identify. Now I am no longer a refugee for my community members".

To get the sense of individual status and to recover it by using immigrant's ethnic leisure subculture, we can see if from the subculture theory's analyses which emphasize on the status problems. Cohen (1997) stated that "status problems are problems of achieving respect in the eyes of one's fellows" When a people or group of people do not get the recognition , they form small group that redefine them and make them more focus and give them status and identities through this kind of 
practices; Kim (1997) in his research shown that Koreans who were residing in New York were gathering in Korean church which provided middle class Korean to come together and share their mobility among themselves.

To sum up, I would argue that Bangladeshi immigrant's social Cricket Game gathering was more than collective or group solidarity, it facilitated individuals to get recognition through collective national identity building and group solidarity. However, there should not be a contraction that some of the participants did participate the gathering from national feeling or sense of belonging and be proud Bangladeshi. This however for many participants was the primary cause or attraction and through that groups or individual's identification can be achieved.

\section{Conclusion}

In this paper I tried to address Bangladeshi Social Game gathering in Tallinn, a leisure subculture among the Bangladeshi immigrants in Tallinn, Estonia. Identity and status practices have been described through this paper and how it is being implemented through practices. I tried to draw conclusion that leisure subculture is very important for the immigrants where they could get out of the stressful life that they live, considering the fact that migration for many people could be traumatic fact. As Pertes and Rumbaut (1996) pointed out that "we should not only think what makes people ill but also what keeps people healthy. Bangladeshi Social gathering from a game was a place where they not only practiced collective identity, they could feel the sense of belonging, also it provides a space to adapt individual strategies to perform and gain identity though that practices. This paper also gives an important indication that through observation and ethnography one can study this group of people and its insight though leisure sub cultural practices.

\section{References}

Cohen, A.K. (1997). A general theory of subculture. London: Routledge.

Feagin, J.R. (1991). The continuing significance of race: Anti-black discrimination in public places. American Sociological Review 56(1), pp.101-16

Kim, P.G. 1997. The Structure and Social Functions of Korean immigrant churches in the United States. International migration review, 26 (4), pp. 1370-94.

Kingsdale, J.M. (1973). The poor man's club: Social functions of the urban working class saloon. American Quaterly, 25(4), pp. 472-89.

Li, P.S. (1987). The economic cost of racism to Chinese-Canadians. Canadian Ethnic Studies, 19(3), pp.102-13. 
Nimmerfeldt, G., Schulze, J., and Taru, M. (2011). The Relationship Between Integration Dimentions among Second Generation Russians in Estonia. Studies of Transition States and Societies, 3 (1), pp. 76-91.

Noel, T.J. (1977). The immigrant Saloon in Denver. Colorado Magazine 54(3), p. 200-19.

Pankiw, B., and R.M. Bienvenue. (1990). Parental responses to ethnic name-calling: A sociological inquiry. Canadian Ethnic Studies, 22, pp. 78-87.

Peiss, K. (1986). Cheap Amusements: working women and leisure in turn of the century. New York. Philadelphia: Temple University Press.

Poe, T.N. (2001). The labour and Leisure of food production as mood of ethnic identity building among Italians in Chicago, 1890-1940. Rethinking History, 5(1), pp. 131-48.

Porters a., and R. Rumbaunt. (1996). Immigrant America: A portrait. California: University of California Press.

Roy, S. (1997). Ballroom Blitz. In Dance in the city, edited by H. Thomas. New York: St. Martin's.

Rublee, C.B., and S.M. Shaw. (1991). Constraints on the leisure and community participation of immigrant women: implications for social integration. Leisure of Societe 14(1), pp. 133-50.

Saar, E. (eds) (2009) Immigrant Population in Estonia. Statistics Estonia: Tallinn.

Schulze, L.J. (2014). The Ethnic Participation Gap: Comparing second generation Russian Youth and Estonian Youth. Journal on Ethno politics and Minority Issues in Europe, 13(1).

Stoldolska, M. (1998) Assimilation and Leisure constraints: Dynamics of Constraints on leisure in immigrant populations. Journal of Leisure Research 30(4), pp. 521-51

Stoldolska, M and E.L. Jackson. (1998). Discrimination in leisure and work experienced by a white ethnic minority group. Journal of Leisure Research 30(1), pp.23-46.

Strauss, A. and J. Corbin. (1990). Basics of Qualitative Research: Grounded theory process and Techniques. Newbury Park, CA: Sage.

Tammaru, T. (2003) Urban and rural population change in Estonia: Patterns of differentiated and undifferentiated urbanization. Tijdschrift voor Economische en Sociale Geografie 94(1), pp. 112-223. 


\title{
Summary
}

\section{Identity practice: A study of Bangladeshi Immigrants Leisure Subculture and Identity Practices in Tallinn, Estonia.}

\author{
Aminul Islam \\ Institute of International and Social Studies, Tallin University, Estonia
}

This paper addressed Game gathering in Tallinn, Estonia from the perspective of leisure subculture among Bangladeshi immigrants. By describing Identity and status practices, this paper figured how it is implemented through their leisure practices. This study also addressed the fact that leisure subculture is very important for the immigrants in order to get out of their stressful life as for many of them migration itself can be traumatic fact. Through ethnography this paper came up with the conclusion that leisure subculture provides a social cohesion which leads the immigrants to practice their different identity and status from within the community. This paper also argues that apart from collective identify, this kind of leisure subculture gathering gives recognition of an individual's identity and status. Social gathering in the form of playing game of cricket was a place where the Bangladeshi immigrants not only practiced collective identity, they could feel the sense of belonging, also it provides a space to adapt individual strategies to perform and gain identity though that practices.

Keywords: Subculture, Immigrants, Tallinn, Estonia, Identity, Refugee. 